\title{
Current status of Great Bustard Otis tarda in Turkey: population size, distribution, movements, and threats
}

\author{
İBRAHİM KAAN ÖZGENCİL ${ }^{1,2,3 *}$ (D), FERDİ AKARSU ${ }^{2,4}$, \\ MEHMET MAHIR KARATAŞ ${ }^{5}$ (D), ARZU GÜRSOY-ERGEN ${ }^{6}$ (D), \\ FULYA SAYGILI-YİĞİT ${ }^{7}$ (D), MUHARREM KARAKAYA ${ }^{5}$ (D) and \\ MELISA SOYLUER ${ }^{1,3}$ \\ ${ }^{1}$ Department of Biological Sciences, Middle East Technical University, o680o, Ankara, Turkey. \\ ${ }^{2}$ Doğa Derneği (BirdLife Turkey), 35460, İzmir, Turkey. \\ ${ }^{3}$ Simurg Bird Sanctuary, o680o, Ankara, Turkey. \\ ${ }^{4}$ International Crane Foundation, 53913, Baraboo, Wisconsin, USA. \\ ${ }^{5}$ Department of Biology, Eskişehir Osmangazi University, 26040, Eskişehir, Turkey. \\ ${ }^{6}$ Department of Biology, Ankara University, o61oo, Ankara, Turkey. \\ ${ }^{7}$ Department of Biotechnology, Niğde Ömer Halisdemir University, 26480, Niğde, Turkey.
}

*Author for correspondence; email: kaanozgencil@gmail.com

(Received 02 March 2021; revision accepted 17 June 2021)

\section{Summary}

The Great Bustard Otis tarda is a globally threatened species with populations inhabiting the steppe zones of Turkey. In recent decades, its populations in Turkey have suffered severe declines in range and size. Although the remaining populations are in urgent need of protection, there has been no national-scale study on the species since 2009, and huge information gaps remain concerning its range, abundance, and movements in the country. Here, we combined data from five years of fieldwork together with all available sight and literature records to present up-to-date estimates of distribution and population size in Turkey, to better understand its movement patterns, to reveal its recent and historical population changes, and to assess its national extinction risk and threats. We find that the species' breeding population has shrunk by $20-29 \%$ over the last five years, and there are only 559-780 breeding Great Bustards in Turkey distributed in two discrete subpopulations. Comparison with historical records shows that the species' range has shrunk by at least $60 \%$ since the beginning of the 2oth century. We suggest possible migratory routes within and through Turkey and that Turkey might have a higher regional importance for the species than previously thought. Illegal hunting, agricultural intensification, shift to irrigated crops, overgrazing, collision with powerlines, and disturbance are the most severe threats to the species in Turkey. Our national Red List assessment yields an Endangered categorisation. Further studies are needed to understand the metapopulation structure and movements of the species and to conserve its remaining populations in Turkey.

Keywords: Conservation, farmland bird, grassland bird, Red List, threatened species 


\section{Introduction}

The Great Bustard Otis tarda is a globally threatened species that once naturally inhabited steppe in the grassland zones of Asia, Anatolia, Europe, Britain, and North Africa (Kollar 1996, Nagy 2018). However, the species adapted to live in agricultural mosaics and thrived in the areas of lowintensity disturbance and cultivation (Lane et al. 2001, Moreira et al. 2004). Nevertheless, because of ever-increasing habitat loss and disturbance resulting mostly from agricultural intensification and hunting, the species has suffered dramatic declines throughout its range, it became extinct in many localities in the last century, and has been listed as globally 'Vulnerable' since 1994 (BirdLife International 2017). According to the latest estimate, there are only 43,847-56,695 Great Bustards in the wild (Alonso 2014).

The Great Bustard subspecies present in Turkey is the nominate Otis tarda tarda (BirdLife International 2017). The species is distributed in the steppe zone of Turkey, which happens to be one of the habitats suffering the most severe destruction and the lowest effective protected area coverage, with only $1.5 \%$ of its surface being effectively conserved (Kirwan et al. 2010, Ambarlı et al. 2016). With 21 sites triggering Important Bird Area (IBA) criteria for Great Bustards (Eken et al. 2006), Turkey once was a stronghold for the species, which occurred in more than 80 localities and had 3,000-4,000 breeding individuals (Goriup and Parr 1985, Kasparek 1989). The Great Bustard population in Turkey has been thought to be made up of two subpopulations: one occupying the inner part of the western $2 / 3$ of the country and the other occupying the eastern $1 / 3$ (Kirwan et al. 2010). Due to widespread habitat loss, agricultural intensification, and illegal hunting, the species' range in Turkey has shrunk substantially, and its population has declined by around $70-77 \%$ over the last four decades (Goriup and Parr 1985, Özbağdatlı et al. 2004). Consequently, the species was listed as 'Endangered' (EN) in the most recent national Red List assessment (Kılıç and Eken 2004), but the last national-scale study of the species was over a decade ago (Karakaş and Akarsu 2009), and its current status in the country remains mostly unknown. According to the most recent estimate produced upon request by BirdLife International, there were $700-1,180$ Great Bustards in Turkey in 2016 (BirdLife International 2021).

Here, by combining data from our fieldwork over the last five years with monitoring studies conducted by public institutions, sightings submitted to online databases, and literature searches, we aim to (i) provide up-to-date distributional and population estimates for the Great Bustard in Turkey, (ii) investigate its mostly unknown in-country movement patterns, (iii) conduct a new national Red List assessment, (iv) determine the identity and intensity of the threats facing the species, and (v) make recommendations to guide future studies and to ensure the protection of the remaining populations.

\section{Methods}

\section{Field surveys}

Geographic coverage of our studies is shown in Figure $S_{I}$ in the online supplementary material. Most data for the inner-western and central Anatolia populations came from our studies and observations conducted over the last five years, while we referenced other studies for information on most populations in eastern Turkey. The majority of the studies we conducted in inner-western and central Anatolia involved monthly observations spanning multiple years, while the remaining ones were single-year studies conducted in spring and summer. Except for the studies we conducted near the Syrian border, which involved multiple-year winter surveys, our eastern Turkey studies involved single-year surveys conducted in the breeding season. Our fieldwork involved some intense and opportunistic data collection in regions of known occurrence, as is the case with most red-listed species (Dormann 2007). Still, most of our fieldwork consisted of unbiased sampling following survey methods mentioned or recommended in Alonso and Alonso (1996), Lane et al. (2001), and Alonso et al. (2004). The method we used most frequently was driving in vehicles 
slowly along transects (15-20 km/h on average; Alonso and Alonso 1996), with transects around 1$2 \mathrm{~km}$ apart, assuming a maximum detection distance of 700-800 $\mathrm{m}$ (Alonso and Alonso 1996). Teams consisted of at least two experienced observers equipped with binoculars and telescopes. We also used vantage points to scan large areas using telescopes. Great Bustards show high sex-size dimorphism, resulting in undercounting of the smaller females (Alonso and Alonso 1996), so we noted numbers of females and males separately whenever possible and used sex ratio estimates from some reliable studies conducted in Turkey, which ranged between 1:1.38 and 1:1.75 (male: female; Heunks et al. 2001, Gürkan et al. 2003, Özbağdatlı et al. 2004, Karakaş and Akarsu 2009, Tanriverdi 2015), to improve our population size estimates. We also documented all possible threats to the species during this fieldwork.

\section{Population size estimates}

Evidence from our own fieldwork, published literature (Table $\mathrm{S}_{1}$ ), monitoring surveys by the General Directorate of Nature Conservation and National Parks, surveys by BirdLife Turkey in central and south-eastern Anatolia, the eBird database (eBird 2019), and sight records and photographs from a national database (TRAKUS 202I) were combined to make the population size estimates. We estimated a minimum and maximum population size for most of the sites to account for uncertainty.

To present the most up-to-date population size estimates, we excluded records before 2018 except for populations for which the only records were from before 2018. In those cases, we used the most recent records available, but applied to them a decline factor determined by the mean population size decline in the country (see Results). We obtained the final breeding and wintering population size estimates by summing all the local estimates. We also reviewed all the studies reporting Great Bustard population size estimates in Turkey to present a picture of the population changes over the last 50 years (Table $\mathrm{S}_{1}$ ).

\section{Distribution and movements}

Given the extreme hunting pressure on the species, we provided no point locations on our maps. Instead, we used $50 \times 50 \mathrm{~km}$ UTM grid squares to present the distributional range of the species. This method also allowed us to account for uncertainty in the reported location of some historical records. Great Bustards display in an exploded lek system, in which, earlier in the season, displays take place in large and compact flocks, which then "explode" over a larger but clearly defined space, where males display solitarily, but mostly within visual reach of each other (Morales et al. 200I). In this type of lek system, the whole lek is detectable only when the smaller aggregations are mapped over a larger scale (Burnside 2012). In the current study, we defined Great Bustard localities as areas having at least one or multiple closely located leks. We also projected the known leks on a map to check how many of them are found within the IBA network in Turkey (Kıliç and Eken 2004) by using ArcGIS Pro 2.6 (ESRI 2020).

We reviewed all the sources used for the population estimates (see above, also Table $\mathrm{S}_{1}$ ) to evaluate the historical distribution of the species. We assessed the current distributional range by using the most recent location estimates. We utilised all our data sources along with some publications from other countries in the species' range (e.g. Farago 1990, Streich et al. 2006, Geacu 2016) to estimate the potential movement patterns of the species within and through Turkey.

\section{National Red List assessment}

We obtained the life history information about the species from BirdLife International (2021), and used the Guidelines for Using the IUCN Red List Categories and Criteria Version 14 (IUCN Standards and Petitions Committee 2019) along with Guidelines for Application of IUCN Red List Criteria at Regional and National Levels Version 4.0 (IUCN 2012) to assess the Red List 
category of the breeding Great Bustard populations in Turkey. See Appendix $\mathrm{S}_{1}$ for the detailed methodology followed to make the assessment. We measured the area of occupancy and extent of occurrence (IUCN Standards and Petitions Committee 2019) by using ArcGIS Pro 2.6.

\section{Threat assessment}

We used data collected during our field surveys, all the Great Bustard studies conducted in Turkey, and national and international species action plans (Appendix S2, Table S2) to determine the threats Great Bustards face in Turkey. We quantified how many of these studies reported each threat type and assessed each threat type's impact level (three levels: low, medium, high) by referring to the studies reporting them and our own observations.

\section{Results}

\section{Distribution, population estimates and movements}

The national population of Great Bustards in Turkey is made up of two seemingly discrete subpopulations as indicated in previous studies (Kasparek 1989, Gürkan et al. 2003, Özbağdatlı and Tavares 2006, Karakaş and Akarsu 2009, Usta et al. 2016): one in inner-western and central Anatolia (henceforth the western population) and one in eastern and south-eastern Anatolia (henceforth the eastern population; Figure Ia). These two subpopulations seem to be separated by the Anatolian diagonal, a well-known biogeographic barrier (Figure 1a; Ekim and Güner 1986, Gür 2016).

The current estimated breeding population size of the Great Bustard in Turkey is only 559-780 individuals, which is $20-29 \%$ smaller than the last estimate in 2016 and $27-38 \%$ smaller than the estimate in 2004 (Table $\mathrm{S}_{1}$ ). The species' breeding range has shrunk by around $65 \%$ since the early 2oth century, and the populations in north-west Turkey have completely disappeared (Figure 1a). More recently, breeding populations along the Syrian border and in the eastern Mediterranean region have also gone extinct, possibly due to agricultural intensification and a shift to irrigated farming in these regions (Eken et al. 2006). The two remaining populations in Turkey are distributed in as few as 26 localities. Twenty of the 27 leks in these localities are totally, and three of them partially, located within the IBA network. Twenty of the 27 leks are very small with fewer than 30 individuals (Figure $S_{2}$ ). The western population holds around 359-500 individuals (almost two-thirds of the national total), the eastern population around 200-280.

We estimated the wintering population size of Great Bustards in Turkey as 593-775 individuals. The previous estimate was 400-1,000 individuals (Kılıç and Eken 2004). Currently, most of the wintering populations are found in central Anatolia and south-eastern Turkey (Figure Ib): 468630 individuals winter in inner-western and central Anatolia, and 120-140 individuals winter in south-east Anatolia. The wintering range of the species has shrunk by around 61\% since the beginning of the 2oth century (Figure $1 \mathrm{~b}$ ), and wintering grounds in south-eastern Turkey, which used to harbour as many as 800-1,000 in winter (Kilıç and Eken 2004), now only host 100-120 individuals. A list of all Great Bustard localities and their population size estimates is available upon request from the corresponding author.

Migratory movements of the species in Turkey are still mostly unknown (Figure 2). The breeding populations in central Anatolia are mostly resident and perform facultative, shortdistance migrations, which seem to be driven mostly by snowfall (Kasparek 1989, Özbağdatlı et al. 2004). However, several old and recent records (OST 1975, Goriup and Parr 1985, Kasparek 1989, eBird 2019) indicate that during harsh winters birds in the western population might leave their breeding grounds for the warmer Mediterranean coast (Figure 2). Nevertheless, the western population stays mostly within central Anatolia and congregates in a few IBAs in winter (Karataş et al. 2021). The eastern population is migratory, and has historically wintered in the eastern Mediterranean Turkey and south-eastern Turkey (Özbağdatlı et al. 2004, Kirwan et al. 2010). Studies in eastern Turkey, surveying the migrating Great Bustards and reporting their directions of 

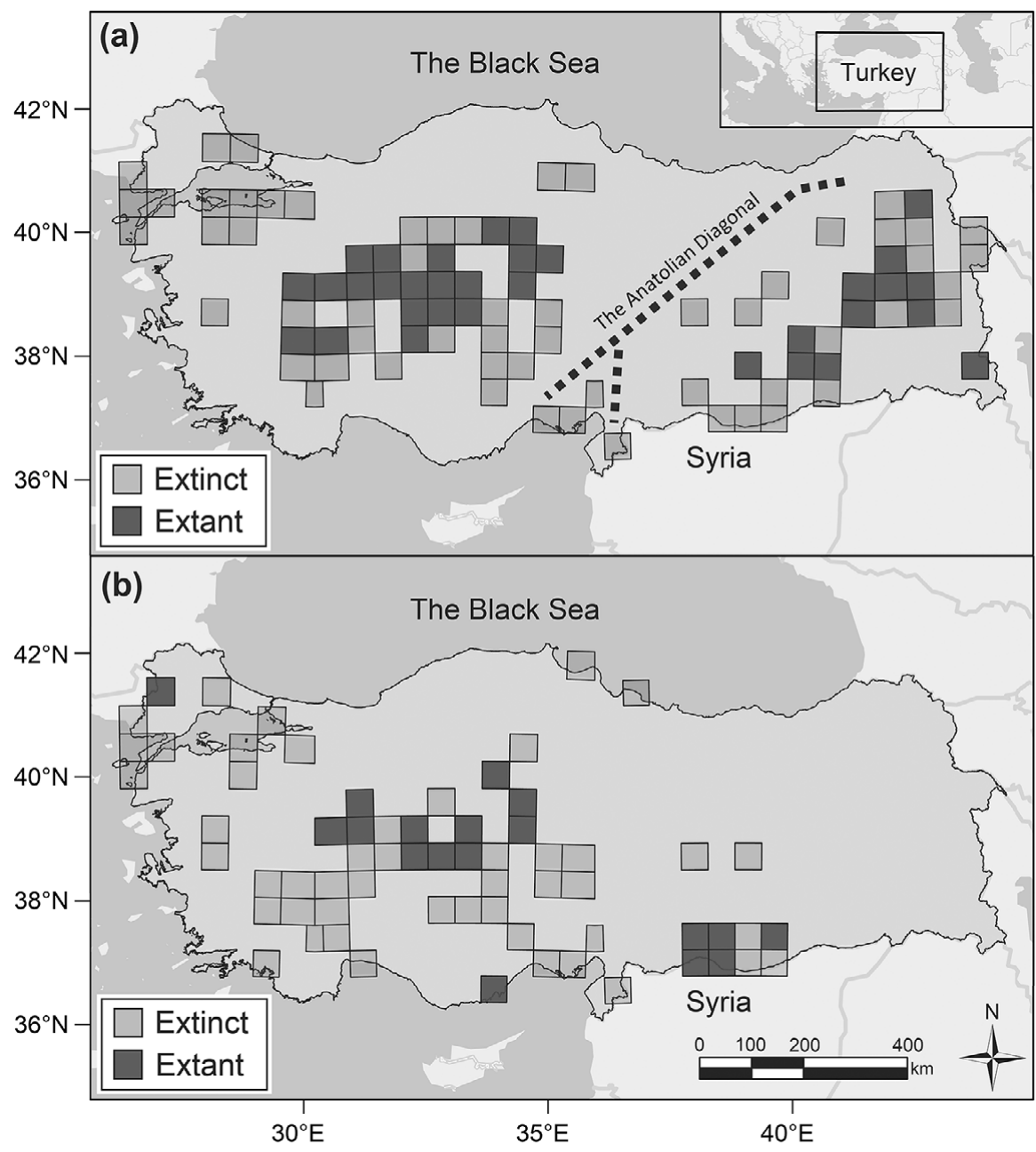

Figure 1. Maps showing the historical and current distributions of the breeding (a) and wintering (b) Great Bustards in Turkey.

flight, provided supporting evidence for the north-east/south-west migration route to and from near or beyond the Syrian border (Figure 2; Tanriverdi 2015).

Other Great Bustard movements in Turkey are less certain. Several historical and recent records of migrating Great Bustards from the deltas on the Black Sea coast, Istanbul, the Bosphorus and Thrace (Goriup and Parr 1985, Kasparek 1989, Karakaş and Akarsu 2009, Kirwan et al. 2010, eBird 2019) suggest some previously undescribed migratory movements involving small numbers of birds along the Black Sea coast and across the Bosphorus (Figure 2). It is even possible that some birds breeding in Russia might be migrating through eastern Turkey, as suggested by observations of several hundred migrating individuals, which is simply too many to originate only from Turkey (Tanriverdi 2015).

\section{National Level Red List assessment}

We found that, depending on method used (Appendix SI), Great Bustard populations in Turkey have declined by either $64-77 \%$ or $30-74 \%$ over the last 30 years, which equals a span of three 


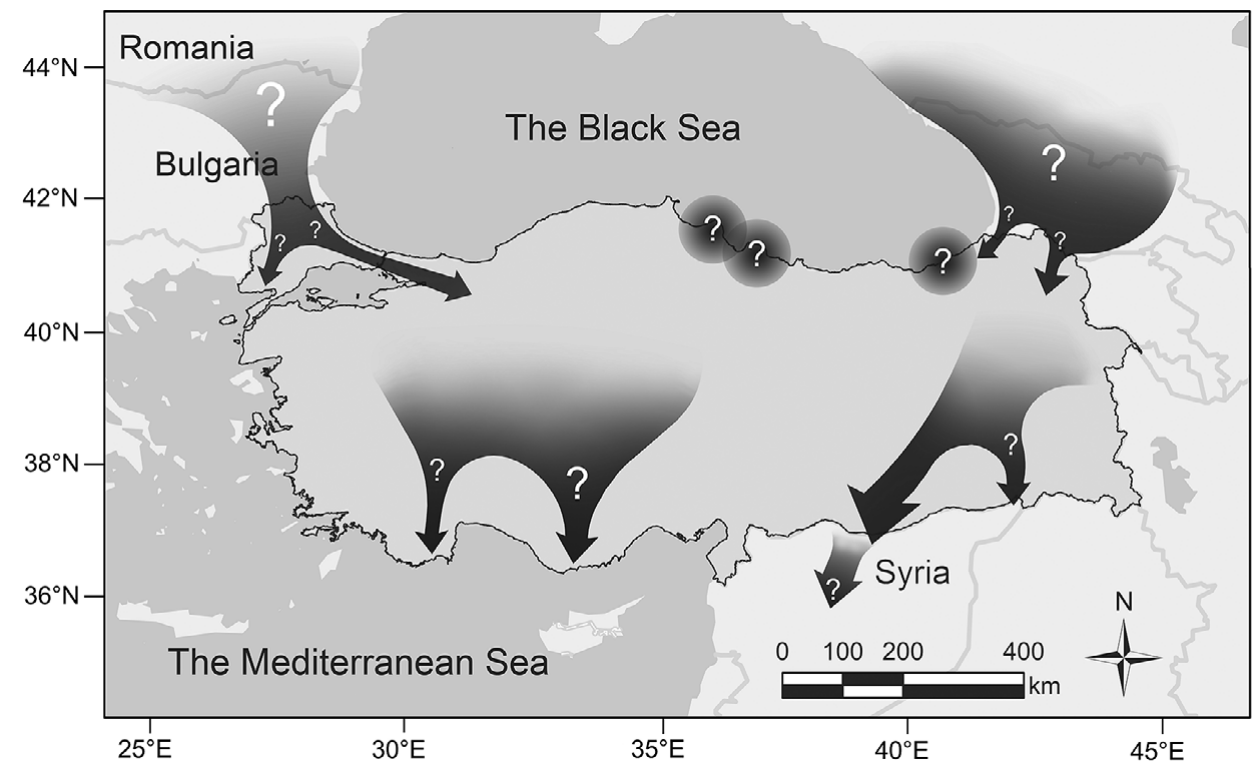

Figure 2. Map showing suspected (the arrows with question mark) and known (the arrow without question mark) post-breeding movements of Great Bustards within and through Turkey.

generations. Both of these estimates resulted in a Aza trigger (IUCN Standards and Petitions Committee 2019) for the EN category. Again, depending on method used, the species' populations have declined by either $28-59 \%$ or $20-27 \%$ over a span of two generations. According to both these results, the $C_{I}$ criterion is triggered for the EN category. Area of occupancy and extent of occurrence triggered no category. Since Turkey's populations do not seem to be substantially connected with populations outside Turkey, we assumed that there is no considerable rescue effect potential. Therefore, we did not change our final category estimate (IUCN 2012). However, we note that the 3o-year decline estimates may not be very reliable because the population size estimates we used give huge ranges (Table $S_{1}$; Appendix $S_{1}$ ). Therefore, our final categorisation for the Great Bustard populations in Turkey is EN with only the $\mathrm{C}_{1}$ trigger.

\section{Threats}

Great Bustards in Turkey are facing a wide array of threats, and those with the most severe impact are illegal hunting, agricultural intensification, disturbance, collision with powerlines, overgrazing, and unchecked use of pesticides in agriculture. Figure 3 gives a list of threats for the Great Bustard populations in Turkey, proportions of the studies reporting each threat, and their impact level.

\section{Discussion}

With 559-780 breeding and 593-775 wintering individuals, Turkey still holds nearly as many Great Bustards as all of its neighbours, the Balkan countries, and Ukraine combined, and ranks seventh in the world in terms of size of the Great Bustard population supported (BirdLife International 202I). However, the country's populations are declining very rapidly, and the remaining numbers are small and face a wide array of threats. 


\begin{tabular}{|c|c|c|}
\hline Threat & Percentage of Studies Reporting & Impact Level \\
\hline Illegal hunting & $95.5 \%$ & High \\
\hline Agricultural intensification/irrigation & $86.4 \%$ & High \\
\hline Human and livestock disturbance & $54.5 \%$ & High \\
\hline Agricultural pesticides & $54.5 \%$ & High \\
\hline Collision with powerlines and wind turbines & $50 \%$ & High \\
\hline Overgrazing & $45.5 \%$ & High \\
\hline Loss of the chicks and eggs during harvest & $36.4 \%$ & High \\
\hline Wetland drainage, dams and unsustainable water use & $31.8 \%$ & Medium \\
\hline Urbanisation & $31.8 \%$ & Medium \\
\hline Collection of the chicks and eggs & $18.2 \%$ & Low \\
\hline Predation by feral dogs & $9.1 \%$ & Low \\
\hline Loss of eggs due to stamping by livestock & $10 \%$ & Low \\
\hline Forestation & $4.5 \%$ & Low \\
\hline
\end{tabular}

Figure 3. Threats for Great Bustard populations in Turkey, the percentage of studies reporting them, and their estimated impact level (three levels: high, medium and low).

\section{Distribution, population estimates and movements}

It has long been suggested that there are two distinct Great Bustard subpopulations in western and eastern Turkey (Karakaş and Akarsu 2009), and our findings support this view. The Anatolian diagonal, which lies between the two populations, is a well-known biogeographic barrier shaping phylogeography and the distribution of various organisms (Nilson et al. 1990, Gül 2013, Mutun and Dinç 2019). The diagonal is located at the eco-regional transitional zone, where there is a sharp environmental gradient (temperature seasonality, precipitation, elevation; Gür 2016). It is because of this that the diagonal is thought to act as a dispersal barrier for many taxa (Gür 2016), and the diagonal may also restrict the dispersal of a weak disperser like the Great Bustard, considering that the females of the species are mostly philopatric to their breeding grounds and the males perform short to medium distance natal dispersal (Alonso and Alonso 1992, Martín et al. 2008). Nevertheless, some historical and recent records from places closer to or along the Anatolian diagonal (Kasparek 1989, Karakaş and Akarsu 2009) and the fact that some of the females from the populations in Central Asia are capable of surprisingly long-distance migrations (Kessler et al. 2013) may suggest that there was or still is some movement across it and that some undiscovered populations may still exist along it, serving as links for gene flow between the two populations. Surveys searching the diagonal for the possible populations and molecular studies employing collection of feathers and/or faeces and subsequent mtDNA sequencing (Martín et al. 2002, Idaghdour et al. 2003) may be needed to solve this mystery.

The Turkish population has declined substantially over the last few decades, and the majority of the remaining leks are very small and at high risk because the extinction rate of a lek increases rapidly below the 30-individual threshold (Pinto et al. 2005). Furthermore, the species has gone extinct in more than half of its Turkish breeding range, possibly rendering the remaining populations more isolated (Martín et al. 2002). The remaining populations should be protected to curb further isolation, and the larger leks (one in Eskişehir province and two in Muş province; Figure $\mathrm{S}_{1}$ ), should be protected with utmost care considering the potential roles of these leks as source populations for other smaller populations (Martín et al. 2002). 
Records of Great Bustards migrating along the Bosphorus and on the Turkish Black Sea coast are intriguing and need more research. Great Bustard populations in central and eastern Europe and Ukraine can perform facultative movements in winter in response to decreasing temperatures and snowfall, reaching as far as Italy, Romania, and Greece (Farago 1990, Kollar 1996, Streich et al. 2006, Geacu 2016). It is possible that some of these wintering individuals might occasionally migrate to the Thracian part of Turkey and across the Bosphorus into Anatolia. Judging by the observations on the ground, suggesting that the populations in Crimea are mostly staying within the peninsula in winter (M. Kessler in litt. 202I), it is more likely that the wintering individuals found in north-western Turkey originate from central and/or eastern Europe. Similarly, the sightings from north-eastern Turkey may be attributable to some birds that breed in the Crimean Peninsula and Rostov and Volgograd, Russia, with the former being less likely. Great Bustards breeding in Crimea might be taking an eastern route along the Black Sea coast when the region experiences harsh winters, and the individuals from the migratory populations in Rostov and Volgograd, which can migrate south-west to winter in Crimea (Oparina et al. 200I, Watzke 2007), might be crossing the Caucasus to reach southern Georgia (as reported by A. Abuladze in litt. 2021) and eventually Turkey. The records in mid-northern Turkey are more difficult to explain. The most plausible explanation for the spring sightings is that the individuals spotted in this region were simply dispersing individuals looking for new leks or conspecific groups (Lane et al. 2001). The winter records from the same region, on the other hand, might suggest that the region served as a wintering ground for the extinct populations in inner northern Turkey. There is also a possibility that the region hosted small groups of wintering individuals from Ukraine and Russia; the individuals reaching north-eastern Turkey might have followed the coastline to reach mid-northern Turkey. The possible and previously uninvestigated movements presented in this section may imply that Turkey used to be or might still be an important migratory corridor or wintering ground for some populations outside Turkey.

Further research is also needed to shed light on the movements of relatively better known western populations. Several winter records from the Mediterranean coast suggest that some individuals might fly south in winter. Research is also needed in eastern Anatolia. Several hundred individuals were spotted migrating through a single locality in one day (Tanriverdi 2015), hinting at an important migratory corridor in eastern Turkey. Such a corridor is also suggested by the astonishing numbers of wintering Great Bustards observed in south-eastern Turkey in the past, which were simply too many to derive from national breeding populations (Kirwan et al. 2010). Some of the birds that visit south-eastern Turkey might be moving further south to winter in Syria. Satellite tracking (e.g. Burnside 2012, Ashbrook et al. 2016) and the use of stable isotopes (e.g. Shaw and Ryan 2015) could help resolve the mysteries surrounding the migratory movements of the species in and around Turkey.

\section{Threats and conservation measures}

Europe has the largest Great Bustard population in the world (Nagy 2018), and the Red List status of the species on the continent is 'Least Concern' (BirdLife International 2015) owing to the large populations in the Iberian Peninsula and slowly growing populations in central Europe (Nagy 2018). Conversely, the population in Turkey is currently EN at the national scale, and constantly shrinking. However, as with many of the other Great Bustard populations in the world (e.g. Horreo et al. 2013, Barati et al. 2015, Vadász and Lóránt 2015, Alonso et al. 2016, Wang et al. 2018), leading causes of Great Bustard population declines in Turkey are human-related.

Illegal hunting remains a significant and probably the most serious cause of population declines in Turkey. Hunting pressure exists throughout the range of the species in Turkey, and it has been reported as a threat by almost all of the studies that have been conducted in Turkey. Effective wardening and the involvement of local people in conservation, which has proved to be a very successful conservation tool in other parts of the world (e.g. Gibson and Marks 1995), are needed to 
stop illegal hunting of the species in the country, which will, however, probably remain the most serious threat for the species in the near future.

Agricultural intensification and the abandonment of dry cereals for irrigated cash-crops such as maize Zea mays and sugar beet Beta vulgaris have been widespread in the steppes of Anatolia in recent decades (Yilmaz et al. in prep.), and $86.4 \%$ of studies in Turkey reported this as a threat. Great Bustards are known to avoid irrigated fields (Lane et al. 2001, Sani 2015), and water abstraction and diversion for irrigation (Ambarl et al. 2016) have destroyed wetland habitats and freshwater springs, on which many Great Bustards in Turkey depend (Karakaş and Akarsu 2009). Mechanisation in agriculture causes direct mortality through egg and chick loss during harvest (K1liç and Karakaş 2005, Vadász and Lóránt 2015, Nagy 2018) and provides the opportunity to plough and cultivate hills in the landscape, which were once habitat islands that Great Bustards used as leks (Heunks et al. 2001, Karakaş and Akarsu 2009). Pesticide use, which can harm Great Bustards directly (Karakaya et al. 2017) and/or indirectly by reducing their food supply (Martín et al. 2007) is also a widespread practice in Great Bustard habitats in Turkey (Karakaya et al. 2017). A return to a more traditional agricultural scheme, involving a mosaic landscape of fallow land, semi-natural habitat patches, and various kinds of crop (Lane et al. 2001), with appropriate compensation for farmers for setting aside land, delayed harvest, and lowered use of pesticides, could help preserve the remaining populations.

Overgrazing is widespread in Anatolian steppes, where it threatens various taxa (Ambarl et al. 2016) including Great Bustards. Overgrazing causes severe degradation in steppe habitats, decreasing the amount of high-quality habitat for Great Bustards. We saw during our studies that the situation is grave in central Anatolia, where most of the remaining steppes are overgrazed leaving them with a few non-palatable, thorny plants species that do not serve as good Great Bustard habitats. Designations of fenced no-grazing areas and effective wardening seem to be the only viable means of minimizing this threat.

Disturbance caused by human presence, agricultural activities, vehicle traffic, and livestock herding is another severe threat to the species. Studies elsewhere have shown that anthropogenic disturbance can significantly reduce breeding success in Great Bustards (Rocha et al. 2013, Ponce et al. 2018) and induce flight responses that increase energy expenditure and the risk of collision with powerlines (Kollar 1996, Sastre et al. 2009, Torres et al. 2011). Furthermore, human and livestock disturbance and hunting pressure in Turkey are forcing Great Bustard populations into highly suboptimal and marginal habitats, best exemplified by a population in central Anatolia, which has its lek on small bare islands in a hypersaline lake (Özgencil and Özcan 2018), and by another one, which seems to be breeding in and around a Scots pine Pinus sylvestris forest in eastern Turkey (Per et al. 2012).

Urbanisation is putting additional pressure on the species' populations in Turkey. Apart from the usual problems that come with urbanisation and infrastructure development (Sastre et al. 2009, Torres et al. 2011), railway construction is a particular threat for the species. Many of the species' populations in Turkey are found on state farms, within which agriculture is practiced on large, flat, and continuous pieces of land. Unfortunately, such land is also in demand for building high-speed railways owing to its topography and no-cost expropriation. A few important Great Bustard breeding grounds have already been fragmented as a result, and there is a constant risk of collision with trains for Great Bustards living in these areas.

Collision with powerlines is a major cause of mortality in Turkey. Great Bustards fly fast, but they lack good aerial manoeuvrability owing to their weight and their visual systems are poorly equipped to identify obstacles in the flight path, which result in high rates of collisions with powerlines (Janss and Ferrer 2000, Martin and Shaw 2010, Raab et al. 2011, Keskin et al. 2019). Most central Anatolian populations are located near some sort of powerline (Akarsu 2016, Özgencil and Özcan 2018), and we have found several dead Great Bustards under the powerlines during our studies. This threat can be eliminated by moving the powerlines underground (Raab et al. 2012), but this is expensive, making it hard to realize. Therefore, conservation efforts should better be focused on stopping further powerline constructions in or around the Great Bustard localities. 
Lack of scientific research and constant monitoring is also making the Great Bustard populations in Turkey vulnerable. Most of the populations in Turkey are not monitored regularly. Although a great initiative by the General Directorate of Nature Conservation and National Parks in Turkey to monitor Turkey's existing populations has been providing lots of data since 2016, these efforts are limited by the availability of the resources and field staff. Therefore, large-scale and intensive scientific surveys and monitoring studies are urgently needed, especially in eastern Turkey, which has not received much scientific attention for the last two decades.

\section{Supplementary Materials}

To view supplementary material for this article, please visit http://doi.org/10.1017/ So959270921000289.

\section{Acknowledgements}

We thank Adem Akyol, Umut Tank, Cansu Özcan, and Selami Oral for their help in data collection, Kiraz Erciyas, Güven Eken, Mustafa Çulcuoğlu, Emrah Çoban, Suat Mert, Kerem Ali Boyla, Zülfü Fərəcli, Alexander Abuladze, and Mimi Kessler for providing data, and General Directorate of Nature Conservation and National Parks (DKMP), Ministry of Agriculture and Forestry in Turkey for sharing their survey data, Nigel Collar for being kind enough to do the first review of the manuscript and provide lots of highly useful comments, and the two referees, whose suggestions and contributions have improved the manuscript significantly. Our fieldwork was supported by Eskişehir Osmangazi University (grant numbers 201319008 (2013-64) and 201619A232 (20161345)), by Ministry of Environment and Urbanisation (2018), Ministry of Agriculture and Forestry (2016, 2019), and Doğa Derneği (2016, 2018).

\section{References}

Akarsu, F. (2016) The Great Bustard (Otis tarda) 2016 breeding season in central Anatolia, Turkey. Ankara, Turkey: Doğa Derneği.

Alonso, J. C. (2014) The Great Bustard: Past, present and future of a globally threatened species. Ornis Hungarica 22: 1-13.

Alonso, J. C. and Alonso, J. A. (1992) Malebiased dispersal in the Great Bustard Otis tarda. Ornis Scand. 23: 81-88.

Alonso, J. C. and Alonso, J. A. (1996) The great bustard Otis tarda in Spain: present status, recent trends and an evaluation of earlier censuses. Biol. Conserv. 77: 79-86.

Alonso, J. C., Martín, C., Alonso, J., Palacín, C., Magaña, M. and Lane, S. (2004) Distribution dynamics of a great bustard metapopulation throughout a decade: Influence of conspecific attraction and recruitment. Biodivers. Conserv. 13: 1659-1674.

Alonso, J. C., Palacín, C., Onrubia, A., Aboulouafae, R., Amezian, M., El Idrissi Essougrati, A., El Khamlichi, R. and Noaman, M.
(2016) Alarming decline and range reduction of the highly threatened Great Bustard Otis tarda in Morocco. Ostrich 87: 277-280. Ambarlı, D., Zeydanlı, U., Balkız, Ö., Aslan, S., Karaçetin, E., Sözen, M., Ilgaz, Ç., Gürsoy Ergen, A., Lise, Y., Çağlayan, S., Welch, H., Welch, G., Turak, A., Bilgin, C., Özkil, A. and Vural, M. (2016) An overview of biodiversity and conservation status of steppes of the Anatolian Biogeographical Region. Biodivers. Conserv. 25: 2491-2519.

Ashbrook, K., Taylor, A., Jane, L., Carter, I. and Szekely, T. (2016) Impacts of survival and reproductive success on the long-term population viability of reintroduced great bustards Otis tarda in the UK. Oryx 50 : 583-592.

Barati, A., Abdulkarimi, R. and Alonso, J. C. (2015) Recent status and population decline of the Great Bustard Otis tarda in Iran. Bird Conserv. Internatn. 25: 377-384.

BirdLife International (2015) Otis tarda. The IUCN Red List of Threatened Species 2015: 
e.T22691900A60012031. Available at: https:// www.iucnredlist.org/species/22691900/ 60012031 [accessed o9 February 2021].

BirdLife International (2017) Otis tarda. The IUCN Red List of Threatened Species 2017: e.T22691900A119044104. Available at: https://doi.org/10.2305/IUCN.UK.2017-3. RLTS.T22691900A119044104.en [accessed II February 2021].

BirdLife International (2021) Species factsheet: Otis tarda. Available at: http:// www.birdlife.org [accessed o6 February 2021].

Burnside, R. J. (2012) Reintroduction and conservation of the Great Bustard, Doctoral Dissertation. University of Bath, Bath, UK.

Dormann, C. F. (2007) Effects of incorporating spatial autocorrelation into the analysis of species distribution data. Glob. Ecol. Biogeogr. 16: 129-138.

eBird (2019) Basic dataset. Version: ebd_TR_ relAug-2020. Ithaca, New York: Cornell Lab of Ornithology. [accessed 8 March 202O].

Eken, G., İsfendiyaroğlu, S. and Bozdoğan, M. (2006) Türkiyénin Önemli Doğa Alanları, Ankara, Turkey: Doğa Derneği.

Ekim, T. and Güner, A. (1986) The Anatolian diagonal: fact or fiction? Proc. Roy. Soc. Edinburgh. B. Biol. Sci. 89: 69-77.

ESRI (2020) ArcGIS Pro. v.2.6. Redlands, CA: ESRI. Available at: https://www.esri.co/nu/rcgi/bout-arcgi/verview [accessed February 2021].

Farago, S. (1990) The effect of heavy winters on Bustard (Otis tarda) populations in Hungary. Alatt Közl 76: 51-62.

Geacu, S. (2016) The great bustard (Otis tarda L.) population dynamics in Romania. Romanian J. Geogr. 1: 43-49.

Gibson, C. C. and Marks, S. A. (1995) Transforming rural hunters into conservationists: An assessment of community-based wildlife management programs in Africa. World Development 23: 941-957.

Goriup, P. D. and Parr, D. F. (1985) Results of the ICBP bustard survey of Turkey, 1981. Bustard Studies 2: 77-97.

Gül, S. (2013) Ecological divergence between two evolutionary lineages of Hyla savignyi (Audouin, 1827) in Turkey: effects of the Anatolian Diagonal. Anim. Biol. 63: 285-295.
Gür, H. (2016) The Anatolian diagonal revisited: Testing the ecological basis of a biogeographic boundary. Zool. Middle East 62: 189-199.

Gürkan, Z., Bekir, S. and Özbağdatlı, N. (2003) Great Bustard conservation project: East Anatolia survey report. İstanbul, Turkey: Doğal Hayatı Koruma Derneği.

Heunks, C., Heunks, E., Eken, G. and Kurt, B. (2001) Distribution and current status of Great Bustard Otis tarda in the Konya Basin, central Turkey. Sandgrouse 23: 106-111.

Horreo, J. L., Palacín, C., Alonso, J. C. and Milá, B. (2013) A link between historical population decline in the threatened great bustard and human expansion in Iberia: evidence from genetic and demographic data: Bustards' historical population decline. Biol. J. Linn. Soc. 110: 518-527.

Idaghdour, Y., Broderick, D. and Korrida, A. (2003) Faeces as a source of DNA for molecular studies in a threatened population of great bustards. Conserv. Genet. 4: 789-792.

IUCN (2012) Guidelines for application of IUCN Red List criteria at regional and national levels: Version 4.o. Gland, Switzerland and Cambridge, UK: IUCN.

IUCN Standards and Petitions Committee (2019) Guidelines for using the IUCN Red List Categories and Criteria Version 14. Gland, Switzerland and Cambridge, UK: IUCN.

Janss, G. and Ferrer, M. (2000) Common Crane and Great Bustard collision with power lines: Collision rate and risk exposure. Wildl. Soc. Bull. 28: 675-68o.

Karakaş, R. and Akarsu, F. (2009) Recent status and distribution of the Great Bustard, Otis tarda, in Turkey: (Aves: Otidae). Zool. Middle East 48: 25-34.

Karakaya, M., Karataş, M. and Özelmas, Ü. (2017) Agricultural Pesticides Used in Eskişehir and Kütahya Population Areas of Great Bustard (Otis tarda, Linnaeus, 1758). Commagene J. Biol. 1: 25-30.

Karataş, M. M., Özelmas, Ü. and Erkara, İ. P. (202I) Counting results of Great Bustard (Otis tarda, Linnaeus, 1758) between 2013-2020 in Eskişehir, Kütahya, and Afyonkarahisar Provinces. Commagene J. Biol. 5: 39-50 
Kasparek, M. (1989) Status and distribution of the Great Bustard and Little Bustard in Turkey. Bustard Studies 4: 80-113.

Keskin, G., Durmuş, S., Karakaya, M. and Özelmas, Ü. (2019) Effects of wing loading on take-off and turning performance which is a decisive factor in the selection of resting location of the Great Bustard (Otis tarda). Biol. Divers. Conserv. 12: 28-32.

Kessler, A., Batbayar, N., Natsagdorj, T., Batsuur, D. and Smith, A. (2013) Satellite telemetry reveals long-distance migration in the Asian great bustard Otis tarda dybowskii. J. Avian Biol. 44: 311-320.

Kılıç, A. and Karakaş, R. (2005) Recent observations on the Great Bustard, Otis tarda, in south-eastern Anatolia. Zool. Middle East 35: 99-102.

Kılıç, D. and Eken, G. (2004) Türkiye'nin Önemli Kuş Alanları, 2004 Güncellemesi [Important Bird Areas of Turkey, 2004 update]. Ankara, Turkey: Doğa Derneği.

Kirwan, G. M., Demirci, B., Welch, H., Boyla, K., Özen, M., Castell, P. and Marlow, T. (2010) The birds of Turkey. London, UK: Bloomsbury Publishing.

Kollar, H., compiler. (1996) Action plan for the Great Bustard (Otis tarda) in Europe. Strasbourg: Council of Europe.

Lane, S. J., Alonso, J. C. and Martín, C. A. (2001) Habitat preferences of great bustard Otis tarda flocks in the arable steppes of central Spain: are potentially suitable areas unoccupied? J. Appl. Ecol. 38: 193-203.

Martin, G. R. and Shaw, J. M. (2010) Bird collisions with power lines: failing to see the way ahead? Biol. Conserv. 143: 2695-2702.

Martín, C. A., Alonso, J. C., Alonso, J. A., Palacín, C., Magaña, M. and Martín, B. (2008) Natal dispersal in great bustards: the effect of sex, local population size and spatial isolation. J. Anim. Ecol. 77: 326-334.

Martín, C. A., Alonso, J. C., Alonso, J., Pitra, C. and Lieckfeldt, D. (2002) Great bustard population structure in central Spain: concordant results from genetic analysis and dispersal study. Proc. Biol. Sci. 269: 119-125.

Martín, C., Alonso, J. C., Alonso, J., Palacín, C., Magaña, M. and Martin, B. (2007) Sexbiased juvenile survival in a bird with extreme size dimorphism, the great bustard Otis tarda. J. Avian Biol. 38: 335-346.
Morales, M., Jiguet, F. and Arroyo, B. (2001) Exploded leks: What bustards can teach us. Ardeola 48: 85-98.

Moreira, F., Morgado, R. and Arthur, S. (2004) Great Bustard Otis tarda habitat selection in relation to agricultural use in southern Portugal. Wildl. Biol. 10: 251-260.

Mutun, S. and Dinç, S. (2019) The Anatolian Diagonal and paleoclimatic changes shaped the phylogeography of Cynips quercus (Hymenoptera, Cynipidae). Annal. Zool. Fennici 56: 65-83.

Nagy, S. (2018) International single species action plan for the Western Palearctic population of Great Bustard, Otis tarda tarda. Prepared by BirdLife International on behalf of the European Commission. https://ec. europa.eu/nature/action_plans/docs

Nilson, G., Flärdh, B. and Andrén, C. (1990) Vipera albizona, a new mountain viper from central Turkey, with comments on isolating effects of the Anatolian" Diagonal". Amphibia-Reptilia 11: 285-294.

Oparina, O.S., Litzbarski, H., Oparin, M.L., Vatske, K. and Khrustov, A.V. (2001) Findings on the migration of great bustards of the Saratov Volga region, obtained through satellite telemetry. Current Issues in the Research and Conservation of Birds of Eastern Europe and Northern Asia 480: 81. [In Russian].

OST (1975) Bird Report 1970-73, Ankara, Turkey: Ornithological Society of Turkey.

Özbağdatlı, N. and Tavares, J. P. (2006) The situation of Great and Little Bustards in Turkey, Ankara, Turkey: Doğa Derneği.

Özbağdatll, N., Karauz, S. and Bünyamin, A. (2004) Toy Ulusal Eylem Plan,, Doğa Derneği ve Doğa Koruma ve Milli Parklar Genel Müdürlüğü, Ankara, Turkey: Yenişehir.

Özgencil, İ. K. and Özcan, C. (2018) Tuz Gölü Özel Çevre Koruma Alani'ndaki Toy (Otis tarda) ve Bozkır Kartalı (Aquila nipalensis) Popülasyonlarının Araştırılması, Ankara, Turkey: Doğa Derneği; T.C. Çevre ve Şehircilik Bakanlığı, Özel Çevre Koruma Kurumu Başkanlığı.

Per, E., Özbek, M. U., Uzunhisarcıklı, M. E. and Bilgili, B. (2012) Great Bustard Otis tarda in Turkey: adult female with three chicks at forest edge in Kars province. Sandgrouse 34: 148-150. 
Pinto, M., Rocha, P. and Moreira, F. (2005) Long-term trends in Great Bustard (Otis tarda) populations in Portugal suggest concentration in single high quality area. Biol. Conserv. 124: 415-423.

Ponce, C., Salgado, I., Bravo, C., Gutiérrez, N. and Alonso, J. C. (2018) Effects of farming practices on nesting success of steppe birds in dry cereal farmland. Eur. J. Wildl. Res. 64: I-10.

Raab, R., Schütz, C., Spakovszky, P., Julius, E. and Schulze, C. H. (2012) Underground cabling and marking of power lines: conservation measures rapidly reduced mortality of West-Pannonian Great Bustards Otis tarda. Bird Conserv. Internatn. 22: 299-306.

Raab, R., Spakovszky, P., Julius, E., Schütz, C. and Schulze, C. H. (2011) Effects of power lines on flight behaviour of the West-Pannonian Great Bustard Otis tarda population. Bird Conserv. Internatn. 21: 142-155.

Rocha, P., Morales, M. B. and Moreira, F. (2013) Nest site habitat selection and nesting performance of the Great Bustard Otis tarda in southern Portugal: implications for conservation. Bird Conserv. Internatn. 23: 323-336.

Sani, N. A. (2015) Habitat Suitability Modeling of Great Bustard, Otis tarda, using ENFA and GIS. Pakistan J. Zool. 47: 1545-1553.

Sastre, P., Ponce, C., Palacín, C., Martín, C. A. and Alonso, J. C. (2009) Disturbances to great bustards (Otis tarda) in central Spain: human activities, bird responses and management implications. Eur. J. Wildl. Res. 55: 425-432.

Shaw, J. M. and Ryan, P. G. (2015) Stable isotopes reveal regional movement patterns in an endangered bustard. Austral Ecol. 40: 198-205.

Streich, W.J., Litzbarski, H., Ludwig, B. and Ludwig, S. (2006) What triggers facultative winter migration of Great Bustard (Otis tarda) in Central Europe? Eur. J. Wildl. Res. 52: 48-53.

Tanriverdi, A. (2015) Research on the reproduction ecology of Great Bustard (Otis tarda L., 1758) within the border of Mus Province, Doctoral Dissertation, Yüzüncü Y1l Üniversitesi, Van, Turkey.

Torres, A., Palacín, C., Seoane, J. and Alonso, J. C. (2011) Assessing the effects of a highway on a threatened species using BeforeDuring-After and Before-During-AfterControl-Impact designs. Biol. Conserv. 144: 2223-2232.

TRAKUS (2021) Türkiye'nin Anonim Kuşları. Available at: https://www.trakus.org/ [accessed at February 2021].

Usta, T., Tatar, B., Yıldırım, G., Çatal, H. and Bolat, Ü. (2016) Toy (Otis tarda) Tür Eylem Planı, Ankara, Turkey: T.C. Orman ve Su İşleri Bakanlığı, Doğa Koruma ve Milli Parklar Genel Müdürlüğü, Yenimahalle,

Vadász, C. and Lóránt, M. (2015) Key mortality causes of the Great Bustard (Otis tarda) in Central Hungary: An analysis of known fatalities. Ornis Hungarica 22: 32-41.

Wang, M., González, M. A., Yang, W., Neuhaus, P., Blanco-Fontao, B. and Ruckstuhl, K. E. (2018) The probable strong decline of the Great Bustard Otis tarda tarda population in North-Western China. Ardeola 65: 291.

Watzke, H. (2007) Results from satellite telemetry of great bustards in the Saratov region of Russia. Bustard Studies 6: 83-98.

Yılmaz, G., Çolak, M. A., Özgencil, İ. K., Metin, M., Korkmaz, M., Ertuğrul, S., Soyluer, M., Tuba, B., Tavşanoğlu, Ü. N., Özkan, K., Akyürek, Z., Beklioğlu, M. and Jeppesen, E. (in prep.). Decadal changes in size, salinity and biodiversity in lakes in Konya Closed Basin, Turkey, subjected to climate change and increasing water abstraction for agriculture. Taylor and Francis. London, UK. 